\section{SPD-004 EFFICIENCY OF PRECISION DOSING WITH INTRAVENOUS IMMUNOGLOBULINS IN PATIENTS WITH HAEMATOLOGICAL MALIGNANCIES}

M Dominguez Cantero*, FJ Salmeron-Navas, EM Barreiro-Fernandez, C Moreno-Ramos, MP Briceño-Casado. Hospital Universitario Puerto Real, Servicio De Farmacia, Cadiz, Spain

\subsection{6/ejhpharm-2020-eahpconf.23}

Background and importance Intravenous immunoglobulin (IVIG) therapy is relatively expensive and requires careful use. IVIG dosing is based on actual body weight (ABW) but it is mainly distributed in the extracellular and intravascular space and minimally in body fat. This would allow adjusting the dose by ideal body weight (IBW) or adjusted body weight (AdjBW), reducing the dose per patient.

Aim and objectives The objective of this study was to describe the efficiency of precision dosing (PD) compared with ABW dosing in the initial dose of IVIG in patients with haematological malignancies.

Material and methods This was a retrospective descriptive study from May 2008 to September 2019. Patients with haematological malignancies who had received at least one dose of IVIG were included. Exclusion criteria were: $<18$ years of age and absence of anthropometric and/or clinical data. PD was defined as the use of IBW (Devine formula in men and Robinson formula in women) for dose calculation except: (1) ABW <IBW, dosing with ABW, (2) body mass index (BMI) $\geq 30 \mathrm{~kg} / \mathrm{m}^{2}$ or $\mathrm{ABW} \geq 20 \%$ IBW, dosing based on AdjBW $(\mathrm{Adj} \mathrm{BW}=\mathrm{IBW}+0.5 \times(\mathrm{ABW}-\mathrm{IBW}))$. Variables from the electronic medical record and records of the hospital pharmacy service were sex, age, ABW, haematological pathology and initial dose of IVIG. Efficiency was determined by the difference (in grams) between the initial mean dose (DMI) per ABW versus PD and the percentage cost difference.

Results Of 88 initial patients who met the inclusion criteria, 39 were excluded. The remaining 49 patients, 22 men and 27 women, had a mean age of $60 \pm 18$ years, mean ABW of 74 $\pm 17 \mathrm{~kg}$ and mean BMI of $28 \pm 5 \mathrm{~kg} / \mathrm{m}^{2}$. The results are summarised in table 1.

\begin{tabular}{|c|c|c|c|c|c|}
\hline $\begin{array}{l}\text { Haematological } \\
\text { malignancies }\end{array}$ & $\begin{array}{l}\text { No of } \\
\text { patients }\end{array}$ & DMI (g) & $\begin{array}{l}\text { Mean } \\
\text { PD (g) }\end{array}$ & $\begin{array}{l}\text { DMI vs PD } \\
\text { difference (g) }\end{array}$ & $\begin{array}{l}\text { DMI vs PD cost } \\
\text { difference (\%) }\end{array}$ \\
\hline Immunodeficiency & 38 & $32 \pm 9$ & $25 \pm 5$ & $7 \pm 11$ & $17 \pm 23$ \\
\hline $\begin{array}{l}\text { Autoimmune } \\
\text { haemolytic } \\
\text { anaemia }\end{array}$ & 1 & 22 & 17 & 5 & 23 \\
\hline $\begin{array}{l}\text { Idiopathic } \\
\text { thrombocytopenic } \\
\text { purpura }\end{array}$ & 10 & $33 \pm 11$ & $28 \pm 4$ & $5 \pm 13$ & $7 \pm 35$ \\
\hline Total & 49 & $32 \pm 10$ & $26 \pm 5$ & $6 \pm 11$ & $15 \pm 26$ \\
\hline
\end{tabular}

Conclusion and relevance In our population, the use of PD lowered consumption (in grams) compared with AWB. This dosing strategy can be an efficient and easy measure to implement for routine IVIG prescriptions.

\section{REFERENCES AND/OR ACKNOWLEDGEMENTS}

No conflict of interest.

\section{SPD-005 ECONOMIC ANALYSIS OF OSIMERTINIB IN PREVIOUSLY UNTREATED EGFR MUTANT ADVANCED NON-SMALL CELL LUNG CANCER}

A Ferrer Machín*, LG José Arístides, JA Martín Conde, T Betancor García, M Vera Cabrera, S Hernández Rojas, I González García, K Álvarez Tosco, J Merino Alonso. Hospital Pharmacist, Pharmacy Service, Santa Cruz De Tenerife, Spain

\subsection{6/ejhpharm-2020-eahpconf.24}

Background and importance Osimertinib improves progression free survival (PFS) in previously untreated patients with EGFR mutated non-small cell lung cancer (NSCLC). However, its profitability has not been established in a third level hospital.

Aim and objectives The aim of the study was to evaluate the cost effectiveness of osimertinib in patients with mutated EFGR NSCLC compared with other tyrosine kinase inhibitors (TKIs).

Material and methods This was a cost effectiveness study of osimertinib in patients with EFGR mutated NSCLC in a third level hospital over a period of 1 year of treatment (1 January 2018 to 12 January 2019). The protocol of the hospital was reviewed to include all therapeutic alternatives: afatinib, gefitinib and erlotinib.

The main variable of the study was the incremental cost effectiveness ratio (ICER) of osimertinib compared with other TKIs. Secondary variables included: cost of treatment per month $(€)$, efficacy (life months gained), total cost of treatment $(€)$ and incremental cost of osimertinib compared with other TKIs.

Results The incremental cost effectiveness ratios of osimertinib compared with each TKI were:

- Osimertinib versus erlotinib: $€ 6896 /$ month of PFS.

- Osimertinib versus gefitinib: $€ 7931 /$ month of PFS.

- Osimertinib versus afatinib: $€ 7067 /$ month of PFS.

Abstract 2SPD-005 Table 1

\begin{tabular}{lllll}
\hline & Osimertinib & Erlotinib & Gefitinib & Afatinib \\
\hline Dosage (mg/24 hours) & 80 & 150 & 250 & 40 \\
Cost of treatment/month $(€)$ & 4313 & 2045 & 1227 & 1964 \\
Total cost of treatment $(€)$ & $81516^{*}$ & $22904^{* *}$ & $12515^{*}$ & 20033 * \\
$\begin{array}{l}\text { Incremental cost of osimertinib } \\
\text { compared with other TKIs }(€)\end{array}$ & $\begin{array}{l}\text { Reference } \\
\text { Effectiveness (progression free }\end{array}$ & 1858612 & 69001 & $\Delta 61483$ \\
survival) (months) & & $10.4 \dagger \dagger$ & $10.2 \dagger$ & $10.2 \dagger$ \\
\hline *PFS FLAURA study; **PFS EURTAC study; $\dagger$ FLAURA study; $\dagger \dagger$ EURTAC study. &
\end{tabular}

Conclusion and relevance At the current commercialised price, firstline osimertinib therapy in patients with EGFR mutant NSCLC would mean an incremental cost of $€ 7455 \pm € 439$ per month of PFS gained compared with other TKIs. If we consider a year of treatment, the incremental cost of osimertinib would be an additional $€ 74547 \pm 4388$. The reduction in cost of osimertinib would significantly improve its cost effectiveness profile. The main limitation of this study was that the cost of the complete treatment was calculated using the drug's PVL.

\section{REFERENCES AND/OR ACKNOWLEDGEMENTS}

No conflict of interest. 